\title{
Subaltern strategies and autonomous community building: a critical analysis of the network organization of sustainable agriculture initiatives in Andhra Pradesh
}

\author{
Ashok Kumbamu
}

\begin{abstract}
This paper examines and analyses the organization and functioning of subaltern peasant sanghams (grassroot associations of the poor) and their place-based as well as network-based strategies in building autonomous local communities that challenge the consequences of neoliberal globalization in general and the commodification of agriculture and food in particular. The major objective of the counterhegemonic organizational strategies is to build self-protective and subsistence communities, to mend the metabolic rift between nature and society, and to re-reconstruct social fabric within communities. The question remains is whether place-based autonomous communities can sustain in an increasingly globalizing world. To better understand these political dynamics, I use Karl Polanyi's concept of 'double movement' and examine the making of a double movement in Indian agriculture and its socio-political and ecological implications for the Indian peasantry. I use the organizational strategies and activities of the Deccan Development Society, a prominent non-governmental organization that has been working in Medak district for more than two decades, as an illustrative case study.
\end{abstract}

\section{Introduction}

This paper explores and analyses the organization and functioning of subaltern peasant sanghams (grassroot associations of the poor) and their 
strategies in building autonomous local communities that challenge the process of neoliberal globalization in general and the commodification of agriculture and food in particular. It also examines whether place-based autonomous communities could survive and grow in an increasingly globalizing world.

Critical scholars of Indian agriculture argue that the introduction of the 'Green Revolution' in the mid-1960s has facilitated the development of capitalist relations of production in agriculture and has created a 'commercial revolution' in the countryside by making both agricultural inputs (such as land, labour, and technology) and outputs into essential commodities (Griffin, 1979; Patnaik, 1990). Consequently, this process of commodification has created a market-dependent farming community, has sharpened both socioecological and regional contradictions, and has accelerated the process of the differentiation of peasantry. In a treadmill fashion, the differentiated agrarian structure and associated asymmetrical power relations have played an important role in the wide-spread diffusion of the new technologies (Cleaver, 1972; Dasgupta, 1977; Griffin, 1979; Byres, 1981; Harriss, 1982).

Until the late 1980s, the Indian state actively supported the diffusion of the new technology package by subsidizing fertilizers, seeds, power, and irrigation. But, since the Indian government embarkation on the path of economic liberalization in the early 1990s, revenue expenditure on agriculture and rural development, investments in public agricultural research and extension, spending on irrigation and infrastructure development, the public distribution system of food grains, and farmer credit facilities have gradually waned. Import and export restrictions have been removed on almost all agricultural commodities. These neoliberal economic policies have facilitated the deeper integration of farm communities into the capitalist world system and have gradually withdrawn the state from effective regulation of the agricultural input sector and commodity prices. This deregulation of markets has resulted in the rise in input costs and the collapse in price of agricultural commodities. This has led to a major agrarian crisis, which, in its extreme form, has manifested in mounting farmer suicides (Rao, 2005; Shiva, 2005). As official data show, 150,000 farmers committed suicide across the country between 1997 and 2005. On average, 1 farmer committed suicide every 32 minutes, and 45 farmers every day for 9 years! (Sainath, 2007). Unfortunately, this phenomenon has been escalating.

While the Indian state enthusiastically pursues the neoliberal economic agenda in all socio-economic and public sectors, countermovements in various forms have been gaining momentum and challenging the intrusion of the market system into social and community life, and the dispossession of people from their customary livelihoods and the environment. In India, 
since the independence, myriad social movements have arisen across the country, including peasant, women's, adivasi (tribal people), dalit (so-called untouchables), civil rights, and nationalist movements. These movements have arisen as a response to failures of the developmentalist state. As geographer Paul Routledge observes, 'they represent struggles for cultural, ecological and economic survival, confronted as they are by a seemingly inexorable process beyond their control and accompanied by the apparatus of exploitation, domination and repression' (Routledge, 1993, p. 16) .

Historically, social movements in India have been associated with political parties that cynically manipulate or co-opt them for their own benefit of electoral politics and do not allow them to operate independently. New grassroots social movements have arisen in an attempt to redefine political place, agency, and the mode of action and are often autonomous of political parties, though sometimes they form alliance with 'like-minded' nongovernmental organizations (NGOs) and other civil society groups. They tend to engage in local and issue-based struggles and attempt to create political alternatives by 'empowering' and 'sensitizing' different social groups in civil society (Routledge, 1993, p. 17).

As subaltern historian Ranajit Guha (1989) argues, the new social movements (NSMs) in India are struggling on two levels: (i) at the 'defensive level', in protecting 'civil society from the tentacles of the centralizing state' and market forces, and (ii) at the 'assertive level', in changing civil society from within and proposing an alternative conception of 'good life', which rests on the notion of sustainability, traditional knowledge system, and cultural identities. The assertive dimension of the NSMs often involves 'constructive resistance':

That is, not only do these movements articulate dissent (and often noncompliance) with central and state government policies, but they also actively seek to articulate and implement alternative development practices. Viewing the state-directed development process as inimical to local tradition and livelihood, many social movements actively affirm local identity, culture and systems of knowledge as an integral part of their resistance. (Routledge, 1993, p. 17)

In the realm of agriculture, the so-called new farmers' movements (NFMs) began in the 1970s and operate under different names in specific contexts throughout the country (Brass, 1994, p. 3). Scholars writing on NFMs in India generally agree that these movements are part of the NSMs that have emerged globally as a new phenomenon from the late 1960s onwards (Brass, 1994, p. 6). As discussed earlier, the commodification of agriculture hastened by the Green Revolution has made the peasantry more vulnerable to the price fluctuations in regard to both input and 
output. Therefore, NFMs raised and mobilized farmers around the issues of 'index-linked agricultural output prices, lower input prices, crop insurance schemes, the ending of bureaucratic corruption, and the imposition of rural quotas for entry into higher education and government employment' (Brass, 1994, p. 7). While the Green Revolution has created objective conditions for the rise of the 'new' farmers' movements, the 'Gene Revolution' in the era of neoliberal globalization has facilitated the mushrooming of urban-based NGO and environmental group movements (Kumbamu, 2006; Scoones, 2008).

Apart from these 'new' farmers' and NGO movements, the 'old-style' peasant-based revolutionary parties and organizations that follow the Naxalbari path have been waging protracted armed and militant struggles with a goal to end all kinds of oppression and exploitation of semi-feudal and semi-colonial social formations. They reject the idea of building the peasant movement based on 'economism' or 'economistic reductionism' (Banerjee, 1984, p. 26), which is a basic characteristic of the NFM.

The 'newness' in these farmers' movements when compared with 'oldstyle' peasant movements is identified by agrarian political economist Terence Byres (1994, p. 2) as:

Agency has passed from 'peasant' to 'farmers'; the central focus of rural agitation had shifted from land to prices; the essential agitational form was a non-party one; and distinctive, novel methods of agitation were employed ... broadening of agenda and ideology, to include the environment and women's issues.

The mobilization dynamics and political actions of all these countermovements depend on their political programmes, strategies, and tactics. Evaluation and value judgement of these movements is beyond the scope of this paper. Thus, this paper is limited to the examination of peoples' 'constructive resistance' in reclaiming a range of autonomies in agricultural and rural life: autonomy over natural resources including seeds, food production, markets, media, and the socio-ecological sustainability of their communities. For better understanding of these political dynamics, I use social historian Karl Polanyi's concept of 'double movement' and examine the making of a double movement in Indian agriculture and its socio-political implications for the Indian peasantry.

\section{Polanyi's double movement in the age of neoliberal globalization}

Karl Polanyi wrote The Great Transformation in 1944 and it has been 'recognised as one of the major works of twentieth-century social science' 
(Block, 2003, p. 275). In this 'canonical work', Polanyi provides a new interpretation of the political and economic origins of the rise and fall of nineteenth century civilization and the entailed 'great transformation'. Polanyi's main argument is that the nineteenth century civilization stood on four basic institutions: the balance-of-power system, the international gold standard, the self-regulatory market, and the liberal state, but the primary cause of the great transformation is the self-regulating market.

Polanyi argues that in the process of its evolution, the market system transforms 'isolated markets into a market economy, regulated markets into a self-regulated market' (Polanyi, 1957, p. 57) and that in a selfregulating market economy 'instead of economy being embedded in social relations, social relations are embedded in the economic system' (Polanyi, 1957, p. 57). This transformation in the relationship between society and economy essentializes the commodification of all noncommodities and makes the 'society as an adjunct to the market'. Moreover, this 'disembedded' economy creates a new 'insecurity and social anxiety' (Munck, 2002, p. 18), because it destroys the basic 'forms of integration' 'reciprocity' and 'redistribution'-, which constitute the fundamental social relations (Polanyi, 1957, pp. 46-53).

Contrary to market liberal creed, Polanyi considers that the idea of the self-regulating market is a 'stark utopia' and 'such an institution could not exist for any length of time without annihilating the human and natural substance of society; it would have physically destroyed man and transformed his surroundings into a wilderness' (Polanyi, 1957, p. 3). He further argues that it is impossible to develop and sustain a society 'controlled, regulated, and directed by markets alone', because social relations and political institutions could not be totally embedded in the autonomous market economy (Polanyi, 1957, p. 68). Further, the total subordination of 'fictitious commodities' (such as land, labour, and money) to the market forces would be pernicious to society. In fact, the organization of production of any commodity has to be embedded in social relations, and the state apparatus is required to manage supply and demand for all commodities. Therefore, it is nonsense to speak of the logic of the autonomous and self-regulating market (Block, 2003, p. 282).

According to Polanyi, the expansion of the self-regulating market to fictitious commodities would inexorably spur society to take self-protecting measures against 'the intrusion of market'. This countermovement is 'more than the usual defensive behaviour of a society faced with change', but in fact, it is a reaction against a market-controlled economy which could destroy the 'fabric of society' and social organization of production. 
Polanyi termed the clash between these two contradictory trends self-regulating market and self-protecting societies - as a double movement, which had governed the dynamics of modern civilization (Polanyi, 1957, p. 76):

[Double movement] can be personified as the action of two organizing principles in society, each of them setting itself specific institutional aims, having the support of define social forces and using its own distinctive methods. The one was the principle of economic liberalism, aiming at the establishment of a self-regulating market, relying on the support of the trading classes, and using largely laissez-faire and free trade as its methods; the other was the principle of social protection aiming at the conservation of man and nature as well as productive organization, relying on the varying support of those most immediately affected by the deleterious actions of the market - primarily, but not exclusively, the working and the landed class - and using protective legislation, restrictive associations, and other instruments of intervention as its methods. (Polanyi 1957, p. 132)

Although there are several ambiguities in Polanyi's conceptualization of the 'market economy', 'embeddedness', 'disembeddedness', 'fictitious commodities', and in his assumptions about the character of the state and its role in redistribution, his concept of double movement is still relevant for understanding the spread of the self-regulating markets, on the one hand, and the rise of the self-protecting communities, on the other, in the politics of (anti-)globalization. Neoliberal economic policies have extended a free trade system across the globe and commodified almost everything in social as well as natural world. This tendency has been challenged by de-globalization and decommodification movement(s) with an aim of "reclaiming "everyday life" (the life world) from "big business" (the system)' (Crossley, 2003, p. 297).

It is not clear, however, in Polanyi's writings what constitutes the subjective forces of self-protecting mechanisms and how do they initiate counter-hegemonic movements and how does the contradiction between the objective conditions and the consciousness of subjective forces of self-protection movements resolve? Moreover, it is important to examine whether it is possible to build sustainable self-protecting communities in a globalizing world. To examine this, I use the socio-political and organizational dynamics of dalit peasant mobilization of the Deccan Development Society (DDS), a prominent NGO that has been working towards building autonomous and sustainable communities in Medak district for more than two decades, as an illustrative case study. 


\section{Building social economy and sustainable autonomous communities: the case of the DDS}

In 1983, a group of urban-based professionals from development studies, communication technologies, and social sciences set up the DDS and began working with dalit women, the most marginalized and excluded section of Indian society, in the Zaheerabad mandal (sub-district) of Medak district, with its field station in Pastapur village, and its headquarter in Hyderabad, the capital city of Andhra Pradesh. Within two decades, DDS activities have spread to 75 villages in five mandals in Medak district. In the initial phase, the vision of DDS was to give a leadership to the community groups from outside and facilitate a humane transfer of technology'. But, after learning from past experiences and seeing the intensified farm crisis in the post-reform phase, DDS realized that it is crucial for local communities to take over certain spheres of autonomies to protect themselves from being trampled over by invisible globalising forces'. Then, it has expanded its vision to include autonomous community building to challenge the dooming consequences of the market mechanisms as well as the policies of failed developmentalist state by reclaiming control over natural resources and local socio-political institutions.

The terms such as 'autonomy', 'sovereignty', 'democracy', 'indigenity', and 'participation' have become integral of DDS strategic planning as well as mundane activities. Although mobilizing women and organizing them into sanghams is a typical NGO practice, DDS's special focus on dalits and its alternative development model are unique. The Organization has 5000 dalit women membership and 'has a vision of consolidating these village groups into vibrant organs of primary local governance and federate them into a strong pressure lobby for women, the poor and dalits'. Dalit farmers in the project area are organized into sanghams and form a network in implementing development projects under the guidance of DDS development workers. The sangham network follows the egalitarian guiding principles such as democratic participation, decentralized decisions, equity, and sustainability, and takes an alternative approach to conventional one in project formulation, implementation, and evaluation.

The strategies of DDS in building autonomous communities divide into two broad categories: place-based strategies of community development and network-based solidarity movement. These two strategies and associated activities aim to avert the risks and crises of the market economy and develop and defend autonomous communities. (Table 1). 
Table 1. DDS sangham network activities in building self-protecting autonomous communities

\begin{tabular}{|c|c|c|c|}
\hline $\begin{array}{l}\text { Neo-liberalized Indian state programmes and market } \\
\text { economy mechanisms }\end{array}$ & Crises and risks & Self-protecting activities of the sangham network & $\begin{array}{l}\text { Resulting autonomies } \\
\text { and resistance }\end{array}$ \\
\hline $\begin{array}{l}\text { Spread of industrial, agricultural, and food system; } \\
\text { improper targeting of beneficiaries and inadequate } \\
\text { and inefficient food distribution; subsidy cut }\end{array}$ & $\begin{array}{l}\text { Food insecurity; endangered food } \\
\text { of 'lower' castes }\end{array}$ & $\begin{array}{l}\text { Alternative Public Distribution System through the } \\
\text { Community Grain Fund; Café Ethic (Organic Millet } \\
\text { Restaurant); revival of subaltern food culture }\end{array}$ & Food sovereignty \\
\hline $\begin{array}{l}\text { Diffusion of new agricultural technologies (seeds, } \\
\text { fertilizers, pesticides, etc.) from the Green Revolution } \\
\text { to the gene revolution }\end{array}$ & $\begin{array}{l}\text { Monoculturization; } \\
\text { commodification of seeds and } \\
\text { other inputs; socio-ecological } \\
\text { crises }\end{array}$ & $\begin{array}{l}\text { Agro-biodiversity conservation through the } \\
\text { Community Gene Fund; mobile biodiversity festival } \\
\text { to bring awareness among farming communities }\end{array}$ & $\begin{array}{l}\text { Seed sovereignty and } \\
\text { control over natural } \\
\text { resources }\end{array}$ \\
\hline $\begin{array}{l}\text { Deregulation of the agricultural input sector and subsidy } \\
\text { cut to crucial inputs; deregulation of markets and } \\
\text { withdrawal of the state from effective price regulation } \\
\text { of agricultural commodities }\end{array}$ & $\begin{array}{l}\text { Increased cost of production; } \\
\text { poor price for the produce; } \\
\text { indebted farming community }\end{array}$ & $\begin{array}{l}\text { Ecological agriculture; dalit watershed; organic } \\
\text { cooperative market; eco-enterprise (e.g. } \\
\text { vermicompost project) }\end{array}$ & $\begin{array}{l}\text { Autonomy over } \\
\text { market, sustaining } \\
\text { agriculture and } \\
\text { livelihoods }\end{array}$ \\
\hline Commodification of land & Disappearance of commons & Preserving commons and pastures & $\begin{array}{l}\text { Control over } \\
\text { commons }\end{array}$ \\
\hline Imposition of global scientific/epistemic knowledge & $\begin{array}{l}\text { Dispossession of indigenous } \\
\text { knowledge }\end{array}$ & $\begin{array}{l}\text { Indigenous knowledge documentation and } \\
\text { dissemination through the Community Media Trust } \\
\text { and Community FM Radio for community } \\
\text { awareness; green education }\end{array}$ & $\begin{array}{l}\text { Sustaining knowledge } \\
\text { and autonomy over } \\
\text { media }\end{array}$ \\
\hline Privatization of public services & $\begin{array}{l}\text { Inefficient and inaccessible public } \\
\text { service system }\end{array}$ & $\begin{array}{l}\text { Village Medicinal Commons; community } \\
\text { supported balwadies (kindergartens) }\end{array}$ & $\begin{array}{l}\text { Building autonomous } \\
\text { social service systems }\end{array}$ \\
\hline Spread of GM crops & $\begin{array}{l}\text { Socio-ecological risks and } \\
\text { negative externalities }\end{array}$ & $\begin{array}{l}\text { Anti-GM campaigns, networking, and solidarity } \\
\text { movement; policy lobbying; organic movement }\end{array}$ & Assertive resistance \\
\hline $\begin{array}{l}\text { Pro-technology and pro-market studies conducted by } \\
\text { epistemic professionals and corporate consultants }\end{array}$ & $\begin{array}{l}\text { Hype over technology and gloss } \\
\text { over its negative externalities; } \\
\text { uncertainties }\end{array}$ & $\begin{array}{l}\text { Research conducted by civil society members and } \\
\text { public intellectuals; video documentation by the } \\
\text { Community Media Trust to show the } \\
\text { socio-ecological and health implications of GM } \\
\text { crops }\end{array}$ & Discursive resistance \\
\hline
\end{tabular}




\section{Place-based strategies}

As developmental critic Arthur Escobar suggests, place-based strategies 'rely on the attachment to territory and culture', whereas network-based strategies 'enable social movements to engage in the production of locality by enacting a politics of scale from below' (Escobar, 2001, p. 161). In fact, networks act as instruments for 'the production of discourses and practices that connect nodes in a discontinuous space' (Escobar, 2001, p. 169). These two strategies are complementary rather than contradictory. For Escobar, place-based strategies 'derive greatly from the modes of operation of the networks that are becoming central to the strategies of localization advanced by social movements (and, of course, by capital in different ways)' (Escobar, 2001, p. 169). Particularly in the politics of liveability, 'reclaiming sustainability', as political ecologist Michael Gismondi writes, 'means struggling to define local places and local ecosystems within a network of global system, and starting to build alternatives from the bottom up' (Gismondi, 2006, p. 153).

In response to the negative implications of market-oriented agriculture and food policies, DDS takes up (place-based) community development activities to address the issues of the erosion of biodiversity, livelihoods, indigenous knowledge systems, local food grains, and food security. The sangham network also takes up socio-cultural issues such as child marriage, sexual harassment, child labour, atrocities on women, etc. To mention a few, the sangham network has implemented the following programmes in their pursuit of autonomy over food, land, seeds, and other commons:

- Community Grain Fund Programme (Alternative Public Distribution System): Brought marginalized lands of dalits into dryland cultivation by collectively using natural resource management methods - 'eco-employment'. In this programme, the sangham women and landless labours took land on lease from farmers who are not cultivating and worked collectively in order to acquire extra food grains for their families. Through this collective effort, the sangham network has significantly increased food grain production at the village level. For instance, the sangham network brought over 1000 ha of fallow land under cultivation and remarkably produced extra $800,000 \mathrm{~kg}$ of sorghum in the first year itself of the programme. To encourage the production of traditional crops and to eliminate middlemen in the marketing of produce and to provide a fair price to the producers, the Organization also has established the Deccan Development Society 
Mutually Aided Credit Cooperative Society Ltd. This Co-op works as a safe avenue for the marketing of organic produce. All these efforts are directed towards reaching the main aim of the programme: 'local food production, local food storage, and local distribution'.

- Community Gene Fund Programme (Traditional Seed Banking Programme): Examining market-nature relations, Polanyi wrote that 'land is an element of nature inextricably interwoven with man's institutions. To isolate it and form a market out of it was perhaps the weirdest of all undertakings of our ancestors' (Polanyi, 1957, p. 178). This is doubly true to all elements of nature including seeds. To counter the 'weirdest' phenomenon of seed commodification, the sangham network has been consciously working to decommodify seeds and to keep them as a precious bounty of nature for a sustainable future through community-owned and managed seed banks. Over 500 sangham women participated in this programme and recovered 50 traditional crop varieties in two years and established community seed banks in 30 villages. To encourage farmers to conserve traditional varieties, since 1999, the sangham network has been annually organizing a month-long cultural campaign called the Mobile Biodiversity Festival, which begins on the local harvest festival of Sankranthi (usually 14 January) and ends on 12 or 13 February.

- Dalit Watershed Programme: Built using the indigenous technical knowledge and exclusively targeted at the development of Dalit farmers' marginalized lands to grow the neglected dry land crops such as millets.

With all these dedicated efforts, the sangham women have significantly increased the cultivation of traditional food crops (mainly millets). These initiatives have revitalized the food culture of dalitbahujans (dalits, adivasis, and most 'backward' castes) in the villages of the sangham network, whose main source of food had been various millets until the introduction of the Green Revolution food grains such as rice and wheat into their lives. And, in order to deconstruct the social construction of millets as the food of 'lower' castes and to bring back the 'forgotten food' into urban people's diet, the sangham network has opened a Café Ethnic, an organic millet restaurant, in the town of Zaheerabad. Moreover, with the traditional seed banking programme, the sangham women have become seed producers and givers not only to their co-members of the network, but also to the farmers of dominant castes. 
This has enhanced their intra-household as well as extra-household bargaining position. More importantly, the local seed production activity has decreased the dependency on external inputs and enhanced the 'internal cycle of inputs', which helps healing the metabolic rift between nature and farm community and also restoring the social fabric of society.

\section{Network-based strategies}

With its network-based strategies, DDS has emerged, in the state of Andhra Pradesh, as one of the major advocates of an organic movement, fierce critics of the techno-industrial agricultural production systems in general, and genetically modified (GM) crops in particular. DDS is a member of several regional, national, and international network-based coalition movements. These include the Andhra Pradesh Coalition in Defence of Diversity, a coalition of over 142 civil society organizations in Andhra Pradesh, the Organic Farming Association of India, the South Asian Network for Food, Ecology and Culture (SANFEC), South Against Genetic Engineering (SAGE), GRAIN, and Biodiversity Action for Sustainable Agriculture - Asia (BASA - Asia). DDS also works as the Regional Resource Agency, networking over 500 environmental and civil society organizations, for the government's Ministry of Environment and Forests. In 2007, DDS initiated the All India Millet Network to encourage production of millet, known as 'God's own crop', and 'to ensure not only the food security of the country but also multiple securities such as fodder security, health and nutritional security, livelihood security and ecological security' (www.ddsindia.com, accessed on 28 April 2008).

DSS regularly commissions studies on the socio-ecological implications of ecological agriculture, biodiversity conservation, and the adoption of GM crops. Since the introduction in 2002 of Bt cotton (genetically engineered variety) into Andhra Pradesh, DDS has conducted studies each year on the socio-economic and ecological implications of the new seed. These ${ }^{1}$ have facilitated and stimulated intense discussion about GM crops and their implications for the sustainability of agriculture and farm community (Kumbamu, 2006).

Sangham women have started making a difference in reclaiming sustainability by demanding that, 'their unrecognised voices are heard and acknowledged by the world outside'. In 2001, in order to create an

I Did Bt Cotton Save Cotton Farmers in Warangal (2002-2003), Did Bt Cotton Fail AP Again in 20032004?, Bt Cotton in Andhra Pradesh - A Three Year Assessment (2002-2005), False Hopes and Festering Failures (2005-2006), and Another Year of Doom - Bt Cotton in AP - 2008 (2006-2007). 
autonomous media, a team of 10 dalit women farmers trained in video production and formed a Community Media Trust (CMT). Over a six-year period, the CMT has produced 75 short films on various agricultural and rural issues such as biodiversity, local health care, women and agriculture, GM crops, etc. Recently, they produced three important films to capture farmers' experiences with Bt cotton in Andhra Pradesh and other places: Why are Warangal Farmers Angry With Bt Cotton? (2003), Bt Cotton in AP: A Three Year Fraud (2005), and A Disaster in Search of Success: Bt Cotton in Global South (2006), shot in South Africa, Indonesia, Thailand, Mali, and India. These films won the prestigious UGC-CEC (University Grants Commission-Consortium of Educational Communication) National Award for the Best Educational Video out of 246 nationwide entries from big-named short-film producers and academia from various Indian universities. The latest multimedia publication of DDS-CMT, Affirming Life and Diversity: Rural Images and Voices on Food Sovereignty in South India, a collection of 12 videos and text on various issues of development in South India, was globally launched in Bonn, Germany, as part of the United Nations Convention on Biodiversity, and subsequently launched in India and Canada in 2008. The video production of DDS-CMT not only helps in building space-based network of solidarity movement at the national and global level, but also encourages farming communities in adopting organic food production methods at local and regional levels. To learn more about the process of subaltern production and distribution of community videos at DDS-CMT and its impact on local farming communities, see Mookerjea (unpublished work).

Although all these activities of the sangham network have been challenging the intrusion of the market economy into agriculture, it is difficult to imagine the functioning of the network without the material support and intellectual guidance of urban-based professionals at DDS. Moreover, considering the dependency of DDS on external (international as well as national) funding sources to support the alternative community initiatives, it is difficult to believe that the sangham network would grow further and build an effective countermovement locally against the forces of neoliberal globalization. In fact, it is naïve to believe that building autonomous and subsistence communities alone would counter globalization process without militantly challenging political and economic forces that have vested interests in promoting the new 'great transformation' and in perpetuating oppression and exploitation of subalterns.

Here, I constructed two ideal types (neoliberalism and subsistencism) and explored to some extent the implications of them for subaltern peasantry. This will be taken further in future research to examine how the 
activities of organizations such as DDS fall short of the ideal type and how they pacify militant social mobilization in the region that have been demanding radical transformation in the social relations of production and distribution.

\section{Conclusion}

This paper examined the process and strategies of autonomous community building and its implications for the liveability of dispossessed subaltern peasantry. It also demonstrated the role of post-developmentalist organizations such as the DDS in the creation of a discursive as well as assertive resistance against agricultural globalization and in the cultivation of 'hope' amidst agrarian distress and farmer suicides. DDS has adopted both place-based as well as network-based strategies to build and defend self-protective and subsistence farming communities, to mend the metabolic rift between nature and society, to promote the decommodification of nature, to revitalize indigenous knowledge systems, and to re-reconstruct social fabric within communities. Place-based activities and space-based network movements complement each other in empowering people and building 'counter-hegemonic bloc' against neoliberal globalization.

Sociologist Sourayan Mookerjea (2009) argues that, 'if we re-orient the concept of empowerment "positively" away from its connection to a militant struggle against oppression, not only does "empowerment" lose all meaning, but we have admitted to ourselves only the vaguest conception of the social organization of oppression'. Thus, in order to sustain empowerment and sovereignty and autonomy over local resources and socio-political institutions, the organizations challenging the self-regulating market and the neo-liberalized Indian state through 'constructive resistance' and militant struggles have to dissolve their contradictions and form a united force against the political and economic mechanisms of the new 'great transformation'.

\section{Acknowledgements}

A version of this paper was presented at the Eleventh International Karl Polanyi Conference, 9-11 December, 2008, Concordia University, Montreal, Québec, Canada. I would like to express my gratitude to Gordon Laxer and Fred Block for their critical comments and helpful suggestions on an earlier version of this paper. I am also thankful to Michael Gismondi, Sourayan Mookerjea, and Satoshi Ikeda for discussion and encouragement. I also wish to express my gratitude to the Killam Trusts for awarding me the Izaak Walton Killam Memorial Scholarship (2006-2008). 


\section{Funding}

The Izaak Walton Killam Memorial Scholarship from the Killam Trusts was used while completing this research project.

Ashok Kumbamu is a doctoral candidate in the Department of Sociology at the University of Alberta, Canada. His doctoral thesis focuses on the local adoption of genetically modified crops and its socio-ecological implications for the sustainability of agriculture in Canada and India. Address for correspondence: Ashok Kumbamu, Department of Sociology, 5-21 H.M. Tory Building, University of Alberta, Edmonton, Alberta, Canada T6G 2H4; email: akumbamu@ualberta.ca

\section{References}

Banerjee, S. (1984) India's Simmering Revolution: The Naxalite Uprising, Zed Books, London.

Block, F. (2003) Karl Polanyi and the writing of the great transformation, Theory and Society, 32 (3), 275-306.

Brass, T. (1994) Introduction: the new farmers' movements in India, Journal of Peasant Studies, 21 (3-4), 3-26.

Byres, T. (1981) New technology, class formation and class action in Indian countryside, The Journal of Peasant Studies, 8 (4), 405-454.

Byres, T. J. (1994) Preface, in T. Brass, ed., Introduction: the new farmers' movements in India, Journal of Peasant Studies, 21 (3-4), 1-2.

Cleaver, H. M. (1972) The contradictions of the Green Revolution, American Economic Review, May 1972, 172-186.

Crossley, N. (2003) Even newer social movements? Anti-corporate protests, capitalist crises and the remoralization of society, Organization, 10 (2), 287-305.

Dasgupta, B. (1977) Agrarian Changes and New Technology in India, UNRISD, United Nations, Geneva.

Escobar, A. (2001) Culture sits in places: reflections on globalism and subaltern strategies of localization, Political Geography, 20 (2001), 139-174.

Gismondi, M. (2006) The nature of local reach, in J. Johnston, M. Gismondi and J. Goodman, eds, Nature's Revenge, Reclaiming Sustainability in an Age of Corporate Globalization, Broadview Press, Peterborough, Ontario.

Griffin, K. (1979) The Political Economy of Agrarian Change: An Essay on the Green Revolution, The Macmillan Press Ltd, London and Basingstoke.

Guha, R. (1989) Dominance without hegemony and its historiography, in R. Guha, ed., Subaltern Studies VI, Oxford University Press, New Delhi.

Harriss, J. (1982) Capitalism and Peasant Farming: Agrarian Structure and Ideology in Northern Tamil Nadu, Oxford University Press, Bombay.

Kumbamu, A. (2006) Ecological modernization and the 'gene revolution': the case study of Bt cotton in India, Capitalism Nature Socialism, 17 (4), 7-31.

Mookerjea, S. (2009) Dalitbahujan women's video experiments in Andhra Pradesh, in K. Howley, ed., Understanding Community Media, Sage Publications, London. 
Munck, R. (2002) Globalization and democracy: a new 'great transformation'? Annals of the American Academy of Political and Social Science, 581 (May, 2002), 10-21.

Patnaik, U. (1990) Capitalist development in agriculture, in U. Patnaik, ed., Agrarian Relations and Accumulation, The 'Mode of Production' Debate in India, Sameekdha Trust and Oxford University Press, Bombay and Delhi.

Polanyi, K. (1957) The Great Transformation, Beacon Press, Boston.

Rao, H. Ch. (2005) Agriculture, Food Security, Poverty, and Environment, Oxford University Press, New Delhi.

Routledge, P. (1993) Terrains of Resistance, Nonviolent Social Movements and the Contestation of Place in India, Praeger, London.

Sainath, P. (2007) A Farmer is Committing Suicide Every 32 Minutes, Alternatives International, http://alternatives-international.net/article1394.html, accessed 20 November 2007.

Scoones, I. (2008) Mobilizing against GM crops in India, South Africa and Brazil, Journal of Agrarian Change, 8 (2-3), 315-344.

Shiva, V. (2005) Globalization's New Wars, Seeds, Water and Life Forms, Women Unlimited, New Delhi.

Srinivas, Ch. and Abdul Thapa, S. (2004) A Study on Alternative Public Distribution System: A Novel Initiative of Deccan Development Society, Booksline, Hyderabad. 